year I saw a female, apparently near a nest, in Audubon Park the latter part of May. I have found it in summer also in Cameron parish, near the mouth of the Calcasieu river. The earliest date of arrival at New Orleans is April 18, 1895. I have no records of the fall movements.

(To be concluded.)

\title{
ANATOMICAL AND OTHER NOTES ON THE PASSENGER PIGEON (ECTOPISTES MIGRATORIUS) LATELY LIVING IN THE CINCINNATI ZOÖLOGICAL GARDENS.
}

BY DR. R. W. SHUFELDT.

Plates IV-VI.

ON February twenty-first, 1914, Mr. S. A. Stephan, General Manager of The Cincinnati Zoölogical Company, of Cincinnati, Ohio, wrote me that "Our Passenger Pigeon has been promised to the Smithsonian Institution when it dies. This bird is a female and now about 29 years old, and the last one of a flock of eight that we got in 1878." I have since learned that it was hatched in the Garden.

The specimen of which Mr. Stephan speaks was, beyond all reasonable doubt, the last living representative of its race in the world, - the last, the very last, of the millions upon millions of those birds which were known to pass over certain sections of the United States during their migrations to and from their feeding and breeding grounds. Many of us, whose birthdays date back to the middle of the last century and before, and who resided in the districts where these vast unnumbered hosts of migrating "blue pigeons" darkened the heavens for days at a time, distinctly, remember the cruel, unnecessary slaughtering of those birds, untold thousands of which were never used for any purpose whatever; millions of others of which were slain for their feathers alone, while it is now impossible to form any correct estimation of the number 
supplied to the markets of the time, or of those allowed to remain where they fell to the guns and other weapons of destruction of the army of slaughterers responsible for their extinction. All this is now past history, and will not be further touched upon in this article more than to say, that Ectopistes migratorius is now extinct; and what is here set forth is but a brief account of my personal observations upon the last known example of the species.

From Mr. Stephan, who wrote me on the 7 th of September, 1914, I learn that "our female passenger pigeon died September 1st [1914] at 1 P. M. of old age, being about 29 years old." It was almost immediately packed in ice and shipped to the National Museum at Washington, D. C., where it was received in fine condition on the fourth of that month. On the morning of its arrival, Dr. Charles W. Richmond, Assistant Curator of the Division of Birds of the Museum, requested me, by telephone, to take part in making the record of the specimen.

When first seen and examined by me, the bird was in the possession of Mr. William Palmer of the National Museum, who had been delegated to skin it for Mr. Nelson R. Wood, of the Taxidermical Department, who, I was informed, was to have the honor of mounting it for permanent preservation in the Ornithological Exhibition Rooms of the museum.

I found the bird to be an adult female in the moult, with a few pin feathers in sight, and some of the middle tail feathers, including the long, central ones, missing. The feathers of the abdomen, and especially about the vent, were soiled to some extent, otherwise the plumage of the bird was smooth and good. It had the appearance of a specimen in health, with healthy eyes, eye-lids, nostrils, and mouthparts. The feet were of a deep, flesh-colored pink, clean and healthy, while the claws presented no evidences indicative of unusual age, though not a few of wear. Its weight was not taken.

At my suggestion, the bird was taken by Mr. Palmer to the photographic rooms of the museum, where, at about $11 \mathrm{~A}$. M., it was thrice posed by me for photography. Three $(8 \times 10)$ successful negatives were at once made by the assistant photographer of the institution, giving the specimen on anterior, posterior and lateral views, with about one-fourth reduction. 
Shortly afterwards (1.15 P. м.), Mr. Palmer and I arrived with the specimen at my home (3356-18th Street, Washington, D. C.), and in one of my work rooms (on the third floor, back room) facilities were immediately given him to skin the specimen. Previous to his commencing this operation, I made duplicate $(5 \times 8)$ negatives of the head of the bird with my vertical camera, and successfully developed them in the dark-room, next to where Mr. Palmer had started in to make the skin.

Apart from the legs and wings, when Mr. Palmer had carried the skinning to the base of the mandibles, I made another exposure with the same camera, the subject being the body of the specimen, natural size, on left lateral view. A reproduction of this unusual photograph is shown in Plate I of this contribution, and is valuable on a number of accounts as exhibiting the size of the body; of the eye; position of the trachea; the great size of the pectoralis major muscle, etc. After this, the eyes and brain were consigned to alcohol; and while I was developing the aforesaid plate in the darkroom, Mr. Palmer completed the skinning of the specimen, having set the body aside for me for anatomical description.

Immediately after this we partook of a "late lunch" in the dining-room below, and, at a little before 4 P. M., Mr. Palmer repaired to his home with the skin in his possession, while I went up to my laboratory on the third floor to make a preliminary survey of the body, prior to making any additional photographs that might be necessary for illustration.

There was no fat present anywhere externally, where it occurs in birds to a greater or less extent, between the dermal tissues and the superficial muscles and other structures. I found, on the right side of the abdomen, a slit-like opening, one-half a centimeter in length, which led freely into the abdominal cavity, and from which blood was oozing. This opening I enlarged in order to withdraw the viscera for the purpose of making a photograph of them, previous to proceeding with the dissection of the organs within. This has been my practice for a great many years.

Much to my surprise, I found a quantity of blood (not clotted) in the abdominal cavity, and the right lobe of the liver and the intestine almost entirely broken up, as though it had been done with some instrument. As to the intestine, it was missing alto- 
gether, while the right lobe of the liver was in scattered fragments. The firmer organs were apparently intact, but did not occupy their normal positions. This left but one course for me to adopt. I therefore evacuated the blood, washed out the abdominal cavity carefully, and consigned the entire body to a jar containing fresh, denatured alcohol, which I had purchased for the purpose.

My hope was to have made a dissection, to be photographed similar to my colored plate of a female tame pigeon, which forms the frontispiece to the Key to North American Birds by Dr. Elliott Coues (Revised Edition, 1884), or to my dissection of the young of Phalacrocorax atriceps georgianus (Pl. 18, Fig. 6), where, in either case, all the viscera are displayed and duly lettered. ${ }^{1}$

The colored pigeon plate I refer to should prove helpful to one not especially familiar with the organs and other structures in the Columbidae while reading the anatomical part of the present paper. There is an interesting contribution to the anatomy of Ectopistes migratorius in Audubon's "Birds of America," for which we have to thank the learned Scotch naturalist, William MacGillivray. ${ }^{2}$

This description is devoted almost entirely to the organs and structures included in the digestive system and to the anatomy of certain parts of the air passages. Up to the present time there has been nothing - so far as I am aware - contributed to the myology of the Passenger Pigeon, or to certain other parts of its morphology, while recently I have given a brief, illustrated account of its skeleton. ${ }^{3}$

The Brain: As stated above, Mr. Palmer removed the brain as best he could, after skinning the head of the bird, and it was at once consigned to alcohol.

\footnotetext{
${ }^{1}$ SHUFELDT, R. W. " Anatomical Notes on the young of Phalacrocorax atriceps georgianus." Science Bulletin, Vol. 2, No. 4. The Museum of the Brooklyn Institute of Arts and Sciences, "A Report of the South Georgia Expedition." Edited by Robert Cushman Murphy. (Nov. 5, 1914), pp. 95-101. Pls. 17, 18.

${ }^{2}$ Audubon, John James. "The Birds of America from Drawings made in the United States and their Territories." Vol. V, New York, 1839, pp. 34, 35. Page 35 is devoted to a drawing by MacGillivray giving - anterior view and somewhat enlarged - the digestive tract of an adult male specimen (preserved in spirits) of Ectopistes migratorius.

${ }^{3}$ Shufeldt, R. W. " 'Osteology of the Passenger Pigeon (Ectopistes migratorius). Tне A Uк, Vol. XXXI, No. 3, July, 1914, pp. 358-362, Plate XXXIV. I have also published other papers on the osteology of this bird in the Proc. Zoöl. Soc. of London, Journal of Morphology, American Naturalist, etc.; these are duly cited in 'The Auk' article.
} 
I find the cerebellum to be 8 millimeters long and $6 \mathrm{~mm}$. wide at its middle part. It projects posteriorly considerably beyond the cerebral hemispheres, and exhibits, on its strongly convex posterior aspect, six transverse sulci, in which minute vessels ramify. The optic lobes - one upon either side - are large and of an ellipsoid form; they cover, in either case, the point of radiation of the sulci laterally, which point (the flocculus) is frequently well exposed in tame or domesticated pigeons.

Having the usual form as seen in the Columbida generally, the cerebral hemispheres are in contact with each other mesially and with the optic lobes below. The cerebral vessels ramify superficially upon the surface of each, while between them, posteriorly, the small pineal gland is in view. Upon direct superior view, the cerebral hemispheres nearly shut out the optic lobes from sight.

Anteriorly, the olfactory lobes are well developed and project beyond the hemispheres, - the first pair of cerebral nerves were divided close to them. Likewise, the second pair of optic nerves were divided close to the rather large optic tracts at the base of the brain-mass.

Measuring across the widest part of the cerebral hemispheres, I find it to be a distance of $18 \mathrm{~mm}$., while the length of the cerebral sulcus is $9 \mathrm{~mm}$.

The Eye: In my above cited paper on the osteology of the pigeon, I have already noted the characters of the sclerotic plates (p. 360), and I may add here that the average antero-posterior diameter of the eye is found to be $14 \mathrm{~mm}$., its transverse diameter being about $9 \mathrm{~mm}$. There appears to have been nothing peculiar in the external musculature of this organ, beyond what we find in the typical eye of ordinary existing birds, - the pigeons in particular. Posteriorly, the optic nerve is not surrounded by an "osseous plate," as it is in the Raven. ${ }^{1}$

Internally, the pecten presents nothing unusual, and the lens has a diameter of about $4.5 \mathrm{~mm}$.

$\mathrm{My}$ next procedure in this dissection required me to separate the immense pectoralis major muscle from its origin upon the sternum on the right side, and to deal with the pectoralis secundus and 
pectoralis tertius muscles in a similar manner. Following this operation, I disarticulated the four right costal ribs at the costal border of the sternum, and also the right coracoid at its sternal extremity. This allowed, in part, a turning of the sternum to one side, and permitted a better view of the interior of the thoracic and abdominal cavities.

There was no evidence whatever of the presence of the intestine in any part of its continuity save a piece about $8 \mathrm{~mm}$. in length, where it emerged from the gizzard and the ragged margin surrounding the abdominal boundary of the vent. All the portion referred to was not in the abdominal cavity.

The entire right lobe of the rather large liver was in a disintegrated condition, showing its internal structure, and exposing the organs usually concealed by it to view.

The heart was in its normal position, while the gizzard was rotated to the left side. I discovered no blood clots or parasites of any kind in the abdominal cavity.

Without making very complete dissections, it was nevertheless evident that the three pectoral muscles and the superficial muscles of the back made origins and insertions similar to those in existing Columbida generally.

Os furculum was next disarticulated at its right coracoidal articulation, and the usual muscles and ligaments in the vicinity divided at different points. This admitted of a far more extended view of the organs and structures within the thoracic and abdominal cavities. This view I at once made a five by eight negative of, the reproduction of a photograph of which is here seen in Plate V.

Extremely simple in its network of nerves, the brachial plexus is primarily formed by the union of the last two cervical nerves and the first two dorsal ones. They soon unite as a single faciculus, from which, as usual, the branches are derived to supply the wing.

Passing for the moment to the pelvic basin, I found the kidneys occupying their usual sites, and neither one appeared to present any atrophy or other evidences of disease; they are of equal size and each tri-lobed.

On the other hand, a certain degree of atrophy characterizes the left ovary and its duct,- a condition we might naturally expect in a bird of this age, and one which had lived so long in confinement. 
Beyond this atrophy, the organ is normal and presents nothing worthy of special note. The right ovary is quite rudimentary, so rudimentary, indeed, and associated as it is with the mutilation of the various organs of the abdominal cavity, referred to in a previous paragraph, that, in the absence of a microscopical examination, this ovary and oviduct might be mistaken for something else, though not likely, as I am familiar with its appearance in a great many species of birds, including the Pigeons.

As I am unable to give any account of the intestine owing to the aforesaid absence, I will quote MacGillivray on the subject, his specimen having been an adult male in spirits. Omitting the reference letters to his figure, he says: "The intestine is 4 feet long, 4 twelfths in width, at the narrowest part only 2 twelfths. The duodenum curves in the usual manner, at the distance of three inches. The intestine forms six folds. The coeca are extremely diminutive, being only $1 \frac{1}{2}$ twelfths in breadth; they are 2 inches distant from the extremity; the cloaca [is] oblong."

Neither the large lungs nor any of the air-sacs I examined presented anything peculiar, nor do they depart in any way from those structures as they occur in ordinary large wild pigeons generally. The lungs were very dark, and appear to have been congested at the time of death.

Posterior to these, the spleen, the ovaries, the adrenals, and the pancreas were all either broken up, as described above, or entirely removed, which was the case with the pancreas, as it, in pigeons, occurs in a loop or fold of the duodenal division of the intestine.

For the purpose of further anatomical description, I determined at this point to remove from the trunk various organs and structures that could not well be described in situ. These included the respiratory apparatus, the heart and great vessels, the digestive tract, remains of the liver, etc.

Respiratory and Vocal Organs: As the 1839 octavo edition of Audubon's Birds (Geo. R. Lockwood ed.) is accessible but to the few, I am taking the liberty of quoting here the essential paragraphs of MacGillivray (as cited above) on some of the remaining organs, in that the student may note the agreement or disagreement, as the case may be, with my own observations as set forth below. Be it remembered, however, that MacGillivray's spirit specimen was a male bird, and the one here being described is a female. 
Among other observations left us in the account, he said: "The mouth is very narrow, being only $4 \frac{1}{2}$ twelfths in breadth, but capable of being dilated to the width of 1 inch by means of a joint on each side of the lower mandible." The "joint" he refers to is the quadrato-mandibular articulation, and, so far as I am aware, the arrangement is the same in all pigeons. He continues by saying that "There are two thin longitudinal ridges on the palate, of which the sides slope upwards. The posterior aperture of the nares is $\frac{1}{2}$ inch long, margined with pupillæ. The tongue is $7 \frac{1}{2}$ twelfths long, rather broad and sagittate at the base, with numerous small papillæ, but at the middle contracted to $1 \frac{1}{2}$ twelfths, afterward horny, very narrow, induplicate, and ending in a rather sharp point." 1

MacGillivray gave the shape of the tongue about as I find it in this specimen. It is distinctly longitudinally grooved upon its dorsal surface in the middle line, while it is convex from side to side ventrally. Posteriorly it is deeply and roundly concaved, the free margin of which is embellished with a fringe of minute and delicate papillæ, which are white and about 32 in number. A row similar to these are found upon the posterior free margins of the upper larynx. The rima glottidis is of an elongate, cordate form, with the median apex behind. Its margins are thickened and raised. On its side, the horny part of the tongue measures $14 \mathrm{~mm}$. and its middle longitudinal line $11 \mathrm{~mm}$. Rima glottidis has a median longitudinal length of $5 \mathrm{~mm}$. The laryngeal and hyoidean muscles present nothing peculiar or noteworthy. Behind, the larynx has a transverse diameter of six mm., and each lateral part is rounded posteriorly, being fringed as above described.

William MacGillivray, when he described the anatomy of Ectopistes migratorius for Audubon, was entirely correct when he recorded that "The trachea passes along the left side, as usual in birds having a large crop; its length is $2 \frac{3}{4}$ inches; its breadth varying from $2 \frac{3}{4}$ twelfths to $1 \frac{1}{2}$ twelfths; its rings 105 , feeble; the last ring large, formed laterally of two rings, with an intervening membrane. Bronchi of about 15 half rings and narrow. The lateral

\footnotetext{
1 In my former article in 'The Auk' cited above, I have already given a brief account of the bones of the hyoid arches, so it will be unnecessary to say anything further about them here. R. W. S.
} 
muscles strong, as are the sterno-tracheal, which come off at a distance of $\frac{1}{2}$ inch. There is a single pair of inferior laryngeal muscles going to the upper edge of the last tracheal ring." (loc. cit., p. 34.) To this I may add that a pessulus does not form a part of the lower larynx in this pigeon; apparently there is not even a rudiment of one.

The superior division of the resophagus, twenty-five millimeters in length, is a strong, muscular tube of uniform caliber, and capable of considerable extension. Externally, its fibers run longitudinally. At the distance above mentioned from the buccal extremity, it suddenly dilates into an enormous crop, which, when filled, has an ellipsoidal form, with the major axis transversely disposed. This axis measures about 54 millimeters, while the minor axis or longitudinal one is about one-fourth less.

In a male bird, MacGillivray found the crop much larger, or 63 by 77 millimeters. Below, the crop in the present specimen has nearly a uniform caliber for a distance of 27 millimeters. It is strong and muscular, with muscular plicæ longitudinally raised upon its extreme surface. Still further along, it gradually dilates, to become the proventriculus, which, terminally very considerably enlarged, enters the gizzard or stomach. This latter is placed obliquely in the abdominal cavity as shown in Plate V.

MacGillivray found the gizzard in the male bird much larger than it is in the female here being described. He states that it was two inches and two-twelfths in breadth, and one inch and onefourth in length. The gizzard at hand is but little more than half this size. It has the usual structure found in the Columbre, and I found its internal cavity to contain a dozen or more quartz pebbles of the size of coarse bird-shot. The musculus intermidias of this gizzard is strong and well developed; its form, from two views, is shown in the plates, as well as its internal structure on section.

In a former paragraph I have already described the condition in which I found the right lobe of the liver, when I opened the abdominal cavity, and this leaves but the smaller left lobe for consideration. It has a transverse diameter of 21 millimeters, and an average longitudinal one of some $12 \mathrm{~mm}$., not taking into consideration the three distal processes it presents: a small median one, and one upon either side of double its size. This distal margin is sharp, 
which, to a less degree, is the case with the rounded or convex anterior contoural boundary. On the dorsal aspect there is a deep concavity, which allows the liver to fit itself upon the superoanterior surface of the gizzard.

The right and left bile ducts were not in evidence, and the various divisions of the peritoneum could not be worked out entirely.

Coming to the heart, I find it to have an extreme length of 23 millimeters, and a transverse diameter, above the ventricals, of 14 millimeters. I examined with great care all the vessels entering and leaving its several cavities and their main branches; they are identically the same as they occur in Columba livia, as described by the late T. Jeffrey Parker in his admirable text-book entitled "A Course of Instruction in Zoötomy (Vertebrata)," on page 241, Fig. 56. There is every reason to believe that the internal anatomy of the auricles and ventricles of this heart of the Passenger Pigeon agree, in all structural particulars, with the corresponding ones in any large wild pigeon, as for example $C$. fasciata. I therefore did not further dissect the heart, preferring to preserve it in its entirety, - perhaps somewhat influenced by sentimental reasons, as the heart of the last "Blue Pigeon" that the world will ever see alive.

With the final throb of that heart, still another bird became extinct for all time, - the last representative of countless millions and unnumbered generations of its kind practically exterminated through man's agency.

Were I to go as far as I could into this subject of the anatomy of the Passenger Pigeon, my collected observations would afford matter for several good-sized volumes. Even the mutilated material before me might furnish several chapters on the myology of this species; on the circulatory system; the nervous system; histology of the structures, and a great deal more besides.

In any group of vertebrates, birds included, it is always an advantage to have published the entire morphology of some particular species of a group, as for example a typical pigeon of the genus Columba. Then, with respect to the morphology of species belonging to genera evidently closely related to Columba, it will but be necessary to make record of enough, with respect to their minute and gross anatomy, to establish the fact that our investigations have led us to a point where we can predict, with absolute cer- 



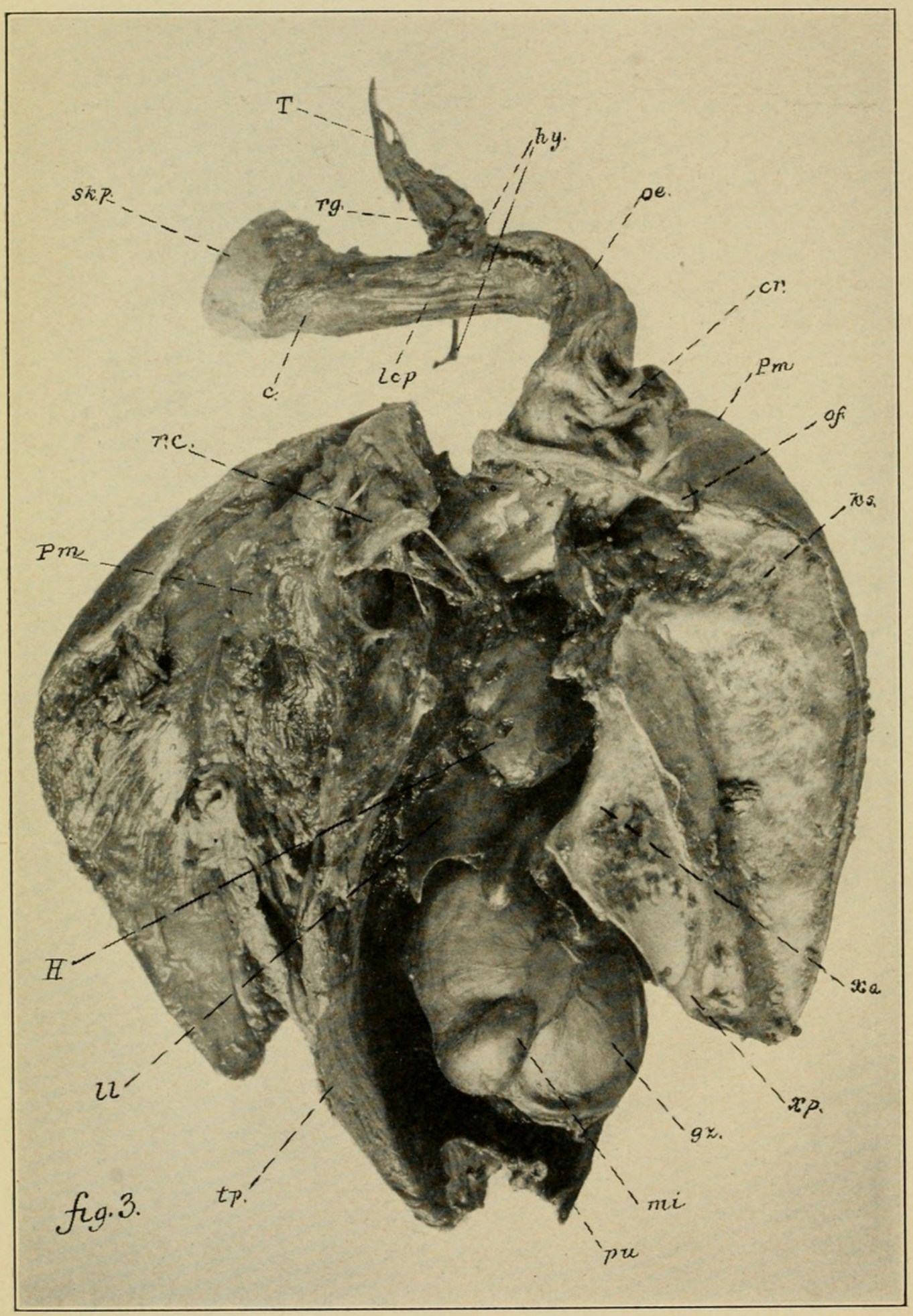

Anatomy of the Passenger Pigeon. 
tainty, what the balance of the morphology will be in any particular case. It is always well, however, to make a careful comparison of the skeleton in the case of all the genera of a family, and it requires a comparative vertebrate morphologist, with a very vast and varied fund of knowledge of his subject, to decide, in any instance, just what amount of data to obtain, in the case of any particular species to be anatomically investigated, when the entire morphology of a typical representative of a closely related genus is known.

If what I have thus far attempted to present of the osteology of Ectopistes migratorius, and of the rest of the anatomy of that species,- and knowing what he already knows of the morphology of Columba livia and other pigeons, - will enable the ornithotomist to surmise, perhaps with more than comparative certainty, what the undescribed parts of the anatomy of Ectopistes migratorius would reveal upon investigation, I feel that my researches have accomplished all that I could hope for in this regard, with respect to our now extinct Passenger Pigeon, and that my labor has been well repaid.

\section{EXPLANATION OF PLATES.}

(All the figures in the Plates are by the author, and made, either by drawing or photographic reproduction, direct from the subjects they depict.)

\section{Reference Lettering.}

aa. internal dermal margin of the auricular aperture.

am. angle of mandible.

c. complexus muscle (Figs. 2, 3.)

cr. crop. (Figs. 3,4 and 4.)

ct. intestine cut away close to the external surface of the gizzard.

dc. depressor caudæ muscle. (Fig. 2.)

e. $\quad$ eye. (Fig. 2.)

el. internal view of eyelids. (Fig. 2.)

gp. gluteus primus muscle. (Fig. 2.)

gz. gizzard. (Figs. 3, 4 and 5.)

$H$. heart. (Figs. 3,4 and 4.)

hy. hyoid with muscles attached. (Figs. 2, 3, 4 and 5.)

ks. keel of sternum. (Fig. 3.) 


\section{$2 \mathrm{BHL}$ Biodiversity Heritage Library}

Shufeldt, Robert W. 1915. "Anatomical and Other Notes on the Passenger Pigeon (Ectopistes migratorius) Lately Living in the Cincinnati Zoölogical Gardens." The Auk 32, 29-41. https://doi.org/10.2307/4071611.

View This Item Online: https://www.biodiversitylibrary.org/item/54104

DOI: https://doi.org/10.2307/4071611

Permalink: https://www.biodiversitylibrary.org/partpdf/88061

\section{Holding Institution}

Smithsonian Libraries

\section{Sponsored by}

Smithsonian

\section{Copyright \& Reuse}

Copyright Status: Public domain. The BHL considers that this work is no longer under copyright protection.

This document was created from content at the Biodiversity Heritage Library, the world's largest open access digital library for biodiversity literature and archives. Visit BHL at https://www.biodiversitylibrary.org. 